\title{
Producing quimeras:
}

\section{lineages of rodents, laboratory scientists and}

\section{the vicissitudes of animal experimentation}

\author{
Marcos Castro Carvalho \\ Museu Nacional, Universidade Federal do Rio de Janeiro, Rio de Janeiro/RJ, Brazil.
}

\begin{abstract}
Taking as my starting point research on knowledge practices in science, this article focuses on analyzing the vicissitudes of animal experimentation and the relationship between researchers and their rodents. The material presented here is the result of an ethnographic study at postgraduate program in biomedical engineering, whose laboratory in question conducts a wide variety of research related to ultrasonic radiation for diagnostic or therapeutic purposes. Many of these research projects use of mice and rats in their experimental setups. Employing historical sources regarding the selection process for murine strains and also ethnographic data gathered during quotidian laboratory procedures, I seek to discuss a specific variation of the agency of laboratory animals by asking the following questions: what do these rodents provoke in science through causing unforeseen through their uniqueness as living beings? What perplexities and questions do the lives and management of these animals produce in relation to scientists and their research?
\end{abstract}

Keywords: laboratory ethnography; animal experimentation; rodents; science.

\section{Produzindo quimeras:}

\section{linhagens de roedores, cientistas de laboratório e as vicissitudes da experimentação animal}

\section{Resumo}

Tomando como meu ponto de partida uma pesquisa sobre práticas de conhecimento na ciência, este artigo foca-se na análise das vicissitudes da experimentação animal e na relação entre os pesquisadores e suas cobaias. O material apresentado aqui é fruto de um estudo etnográfico desenvolvido em um programa de pós-graduação em engenharia biomédica cujo laboratório em questão conduz uma ampla variedade de pesquisas relacionadas à radiação ultrassônica com objetivos diagnósticos ou terapêuticos. Vários desses projetos de pesquisa usam ratos e camundongos em suas montagens experimentais. Empregando fontes históricas relacionadas ao processo de seleção de linhagens murinas e também dados etnográficos do cotidiano laboratorial, pretendo discutir uma variação específica da agência dos animais de biotério a partir dos seguintes questionamentos: o que esses roedores provocam nas ciências por meio de acontecimentos imprevistos e de suas singularidades enquanto seres vivos? Que perplexidades e questionamentos a vida e o manejo dos bichos de biotério produzem em relação aos cientistas e suas respectivas pesquisas?

Palavras-chave: etnografia de laboratório; experimentação animal; roedores; ciência. 


\title{
Producing quimeras:
}

\section{lineages of rodents, laboratory scientists and}

\section{the vicissitudes of animal experimentation}

\author{
Marcos Castro Carvalho
}

This article takes as its point of departure my doctoral research regarding knowledge practices in science laboratories (Carvalho, 2015). Its focus is an analysis of the vicissitudes of experimenting with animals, particularly the forms of quotidian relationships with and the handling of test subjects. The material that I present here originates in ethnographic research that I developed at a university center linked to a graduate program in biomedical engineering, which I call the "Laboratório de Ultrassom Biomédico" (Biomedical Ultrasound Laboratory) or, more simply, the LUB. The LUB undertakes a large and varied number of research projects related to the biomedical use of ultrasound in diagnosis or therapy. A portion of these experiments employ living animals.

A series of bodies are produced and utilized by these experiments with ultrasound radiation. The tissues (organic and synthetic) are prepared in such a way that they become analytically comparable to those of the human body subjected to therapeutic or diagnostic interventions. These bodies include those of the living laboratory test animals, in which cancer and other intestinal inflammations are provoked in order better to produce in vivo diagnostic images. They also include dead bodies, which provide fragmented parts of human and animal cadavers that are submitted to ultrasonic radiation in post mortem studies so that these waves might simultaneously manifest their therapeutic and destructive potential. There are also test bodies known as phantoms, which are produced with synthetic and organic materials mixed together in structures that can be seen or heated by ultrasonic energy "as if" they were living bodies (in vitro studies). And finally, there are virtual bodies, programmed into computers, in which ultrasound is employed according to digital models in a manner that can "foresee" or complement their future applications with experimental bodies (in silico studies).

Therefore, animals and parts of animals circulate in many of the research projects conducted by the laboratory. These might be living experimental animals or simply their dissected body parts. They might be pieces of pork and beef (such as bones, muscles and adipose tissue, livers, kidneys and etc.) acquired in butcher shops, or even commercially available materials developed from animal substances (such as the pigskin gelatin used in the manufacture of certain specimens). Given the vast variety of these bodies and the limits of the present article, our analysis here focuses solely on studies using strains of living rodents. In the case of the LUB, these were undertaken in the context of research involving high frequency ultrasound (or microultrasound), investigating the potential use of this energy in diagnosis. I thus do not intend to address at this time experiments based on industrial materials or fragments of dead animal tissue, regardless of their relevance to a number of experimental procedures currently in progress in the laboratory and present in some or many stages of the studies developed by the LUB (see Carvalho, 2015).

Animals have always been present, in one form or another, in scientific and technical studies. The historical stabilization and consolidation of so-called "vivisection" did not occur in a linear or inexorable manner, however. It began to take shape mainly in the $19^{\text {th }}$ century with Claude Bernard and the increasing hegemony of experimental physiology. One can say that in the $20^{\text {th }}$ century, test animals become imagined 
almost inevitably as rodents, with rats and mice taking pride of place - to the point where "lab rat" has become a synonym for "test animal" in English. It is also in the $20^{\text {th }}$ century that these rodents become massively produced and merchandized in a stable and patterned fashion, becoming privileged research instruments for a variety of experiments, particularly in the health and biological sciences. I have discussed elsewhere (Carvalho, 2015; Carvalho, 2016) the ways in which researchers engage with, relate to and show affection for laboratory animals used in in vivo experimentation, as well as some of the actions, reactions and resistance of these animals to experimental and technical procedures. In this article, I wish to cast light on another aspect of laboratory animals' agency by asking the following question: what do lab animals provoke in science by creating unforeseen situations and through their singularities as living creatures?

Aiming to produce heuristic notes regarding such questions, I have divided the discussions in the present article into two different, but complementary, sections. In the first, I want briefly to address some historical ways in which certain strains of rodents were selected for scientific experimentation. Obviously, given the ethnographic character of my work, I have no intention of conducting a thorough historicizing of the several paths of experimentation with rats and mice, taking account of their disputes and complex intricacies. My selfish use of history as an ethnographic source is intended solely to problematize the essentialized construction of rodents as natural and intrinsic objects for scientific practices. My diachronic establishment of these animals as scientific and technological artifacts simply allows us to illuminate contemporary data, in which the process of "purification" (to use Latour's terms: (1996) and (2000)) of rodents as a working tool necessarily implies dealing with a "hybridism" that precludes the existence of these living beings as mere objects, passive in the face of scientific procedures.

The article's second topic presents a more ethnographic approach to in vivo studies. Through a description of the work on high-frequency diagnostic ultrasound, I relate the ultrasonic biomicroscopy technique performed on mice and rats. I talk about the experimental protocols in which pathological conditions are chemically produced in animals in order to investigate the potential of ultrasound technology in the early diagnosis of gastrointestinal tract disease. In this second section, I thus seek to reveal the problems created by the management of strains of rodents and the mishaps and experimental imponderables these cause. Among these are the daily difficulties and solutions for the stabilization of lab animals as useful tools for experimental setups and theories that guide them, as well as questions regarding the "purity" and "contamination" of the lab animals and the new questions made possible by unforeseen events.

\section{Regarding lab animal strains and their singular characteristics}

Given a special power to cross categorical, typological and moral borders, vampires are monsters that have haunted Europe for centuries. Ambiguous in a series of ways (their human-animal nature, their undead condition, among other potentially scary characteristics), these fictional creations generated both fear and desire in perturbing the European obsession with purity. Like Mary Shelley's Frankenstein (1994[1818]) and the various European vampires, the OncoMouse ${ }^{\mathrm{TM}}$ (the first patented animal in the world ) is considered by Donna Harraway (1999:79) to be a monstrous creature. Simultaneously a natural entity and a human creation, it is a zombie whose existence is simultaneously human and animal, life and merchandise.

Such artefactual rodents cannot be understood as separate from human reality. They are creatures

1 Created-born in the 1980 s through a partnership between Harvard College and the DuPont, biotech company the OncoMouse ${ }^{\mathrm{TM}}$ was patented in 1988 as intellectual property because it carried in its DNA a human gene associated with breast cancer generation. Aside from it being the first patented animal, then, this mouse was also the first genetically modified mammal. 
of the laboratory, the cage, of scientists and their equipment. In a classic semiotic ecological study that is considered to be a seed of modern etiology, Jakob] von Uexküll (1983[1934]) developed the intriguing concept of the Umwelt. Simplifying things somewhat, we can say that Uexkül created this concept in order to account for the worlds developed by animals through their relationships and perceptions as they engaged in activities in environments that were always singular in terms of their characteristics. All of the world-environments described by the author, however, are more-or-less the natural environments of these animate beings. How then can we think of lives and the world of lab rats, in which cages and labs are the relevant environments which these animals share with their peers, with human beings and with (as we shall see below) a series of other agents, living or not? ${ }^{2}$

There is no space in this article to investigate in detail the lives and daily habits of these creatures in their "unknown worlds" (to use one of Uexküll's favorite expressions). This, because what we are doing here is not research into human-animal relationships in all their complex possibilities. Neither are we creating an etiological study. During my research, I did not systematically visit vivariums and these are, obviously, the most important spaces in which these lab animals pass the greater part of their lives ${ }^{3}$. My contact with rats and mice during my field work occurred strictly during the course of experiments, or when I went to collect them from the vivariums, or bring them back in their cages after an experiment. My focus here is thus on the scientific and experimental uses of lab animals and the ways in which these relate to ultrasound technologies (even though I might occasionally refer to things that happened in the vivarium).

Historically, rats and mice did not begin to be raised and selected in lineages with the advent of the use of experimental animals in science. Before this, rodents already were being raised by humans who were trainers and fans of these animals. The controlled reproduction of selected lineages of mice dates from the $17^{\text {th }}$ century (at least) in Japan, gaining much popularity in the U.S. and England in the early $20^{\text {th }}$ century with the establishment of pet fancier organizations. These "amateur" mice raisers were responsible (indirectly so, in most cases) for the creation of the basic conditions for scientific experimentation with animals (Rader 2004: 32-33).

But rodents have not always been science's main lab animal, although they are the principal animal used in research today. According to Karen Rader (2004:16), rodents today make up at least $70 \%$ of the animals currently being used in scientific experiments. One of the first scientists to use rodents was the U.S. American Clarence Cook Little. Little played a fundamental role in the consolidation of Jackson Laboratory in Maine during the first half of the $20^{\text {th }}$ Century. Between 1989 and 2000 , JAX Lab was responsible for supplying some $95 \%$ of the mice lineages used throughout the world (the lab had some $2,400$ strains of frozen embryos) $)^{4}$. In the early 1900 , however, Little was a pioneer, working almost alone in using lab animals in scientific experiments on a large scale.

Little had been presented to the "model mouse" by William Castle (1867-1962), one of his professors at Harvard who had already undertaken research with rats, flies, cats and guinea pigs at the beginning of the

\footnotetext{
2 Giorgio Agamben (2012[2002]) calls attention to a small section of Uexküll's book which might be overlooked in a quick read. In it, the etiologist talks about a tick that was kept alive for 18 years in a lab without being fed, in complete isolation from its environment. Uexküll reads this as a form of waiting that is comparable to a human dreaming. Agamben (idem: 68) thus asks what became of this tick who lived in suspended animation for so long and how is it possible for a living animal, which consists entirely in relation to its singular environment, to live so long isolated from this environment. Here, in the margins of Uexküll's analysis, in his descriptions of animals removed from their original "worlds", something approaching the reality of lab animals.

3 Some ethnographic descriptions of vivariums and their activities can be found in Marras (2009) and Souza (2013).

4 Many uncertainties exist regarding the approximate number of animals annually used in lab testing throughout the world. Although we know that this number is on the order of tens of millions, estimates vary widely. With the growth and spread of animal rights movements, it has become even more difficult to get precise numbers, as the exact numbers of animals used in any given experiment are being publicized less and less (Paixão and Schramm 2008).
} 
$20^{\text {th }}$ Century 5 . As Logan points out (2001), before rodents became stabilized as science's model lab animals, a larger variety of species were serving in scientific experiments. The use of rats and mice raised by animal fanciers was a relevant part of this process, given that much of the research with these animals revolved around studies of genetic inheritance and mutation (Rader, op. cit. p.25-30).

One of the first species of mice to be domesticated and selected by animal fanciers was Mus musculus, the so-called "common rat". Given its long history of breeding by fanciers, it was also one of the first species to be incorporated by scientists into lab work. Mus musculus was one of the main species used by Little. It is still much used in the lab where I conducted my research, although different lineages of the species are used in today's experiments.

Historical "insensitivity" to the use of the mouse as a research animal and to its possible suffering and death may well be linked to moral judgements about the rodent which portray it as sneaky and dirty. In its older habitats, these creatures haunted human spaces such as pantries and granaries. This age old association between rats/mice and humans has resulted in some symbolic baggage (at least in the West) that casts these creatures as tricky and vile scavengers, linked to the transmission of plague and other diseases. They are seen as true tricksters.

Mice have become consolidated as the main reference for lab animals in the modern global science establishment, however. Beginning with the proposal of a cyborg anthropology (which provocatively seeks to reconfigure the borders between humans, organisms and machines through the study of interfaces Haraway (1997:52), the eyes of the mouse may give us a unique ethnographic point of view. Thus,

the relocated gaze forces me to pay attention to kinship. Who are my kin in this odd world of promising monsters, vampires, surrogates, living tools, and aliens? (...) What kind of crosses and offspring count as legitimate and illegitimate, to whom and at what cost? Who are my familiars, my siblings, and what kind of livable world are we trying to build? (idem)

According to Haraway, the 18th and 19th centuries saw the scientific creation of kinship between things that were once understood to be pure and isolated. We see this in the case of Mendeleiev and his innovative periodic table and with Lineu and Darwin in their taxonomical delimitations and linkages of living species ${ }^{6}$. Such classificatory relationships of kinship can be understood as techno-natural objects of understanding, directed towards semiotic and instrumental ends. In this sense, in a certain shifting of our scientific heritage, Haraway argues that the OncoMouse ${ }^{\mathrm{TM}}$ is, in fact, our brother. Or, more specifically, our sister (independent of the fact that the species contains males and females). This because, aside from being a laboratory instrument for the production of knowledge and other technical dispositifs, "her essence is to be a mammal, a bearer by definition of mammary glands, and a site for operation of a transplanted, human, tumor-producing gene - an oncogene - that reliably produces breast cancer" (Haraway, idem: 79).

Rader (2004:36) suggests that, differently from what might appear to be the case, the fact that mice and rats were raised by amateurs for centuries doesn't somehow radically transform their marginal status or make them into domestic animals (although, in practice, they quite obviously are) or pets. To the contrary!

5 At the turn of the century, Mendel's laws also began to be applied to research with animals. But even before rodents became stabilized as the preferential lab animal, genetic studies with Drosophilas flies took place. Mendelianism's entrance into animal studies was particularly productive in the case of the Drosophilas because of the ease and lack of expense in maintaining these insects, as well as their short and intense reproductive cycle, their short lifespans and the fact that they possess only four chromosomes. Mice are relatively more expensive and also vulnerable to various infections. Using the flies, then, let researchers follow a high rate of mutation and genetic variation over a short period of time (Rader, op. cit). For a historical analysis of the use of Drosophilas as an organic model for genetic studies, as well as their consolidation as a privileged species in laboratories, see Hodart (2008). See also Jacob (1998) for historical considerations regarding switches between flies and rats as genetic models.

6 In his preface to "What is an animal?" (1994), Ingold also points out the importance of the genealogical principle in modern biology from Darwin on. François Jacob (1997) holds that the biology of the 19th century inaugurated a double kinship between living beings: a kinship of construction, created by the presence of cells in the "architecture" of all living things; and a kinship of affiliation, created through the theory of evolution. Regarding this theme of rupture between natural history and biology as the science of life, see also Foucault (2000 [1966]). 
The fact that these species have a long history of selective reproduction allowed for them to become massively incorporated into research in a very short time through alliances between amateur breeders and university researchers. If up to the mid-19oos (with rare exceptions) mice simply wandered on their own accord around laboratories in search of food, in the 196os, they became frontline soldiers in research into cancer and mammalian genetics. Some of the amateur breeders even gained a certain notoriety in scientific circles due to the knowledge that they acquired accompanying rodent lineages over the long term. It did not take long, however, for scientists to begin to develop their own systems for the mass production of lab animals via university vivariums. Science thus began to move away from the amateur breeders, who became seen as less scientific and as lacking adequate methods and academic rigor.

A series of arguments have long been employed by scientists in order to justify the use of rats and mice as models for experimental science. Among these, we find the following main arguments:

a. Mice are small and relatively domesticated animals, which means that they are easy to breed, feed and manage in the controlled environments of the vivariums;

b. They reproduce quite quickly (19-21 days for gestation) and with great frequency (many times a year);

c. They have large litters (10 to 24 babies, or even more);

d. They have a relatively short lifespan (a year in the case of mice and maybe two for rats);

e. And, finally, they are mammals and $99 \%$ of their genes are similar to those of humans, with mice developing many of the same diseases that also affect us - in other words, they are close relatives of ours'.

Even though all these explanations make sense, Rader (2004) relativizes the a posteriori pragmatic rationalization of rodents as ideal test animals. He believes that this is much more a result than a cause of the consensus of the biologists of the time. In other words, Rader thinks that the use of these animals ended up producing and determining their utility. This is in part because the homogenization of these animals did not necessarily accompany the development of mammalian genetic studies, which took several years to become consolidated. One must remember here that molecular biology was only created in the second half of the $20^{\text {th }}$ century when the large-scale production of test animals was already well under way.

This sort of a posteriori rationalization is not so necessary today, however, given that the mouse is already widely excepted as the "typical" test animal. The researchers with whom I conducted field work, for example, almost inevitably chose these animals for their tests. After all, they are the most inexpensive and easy to obtain, given the hegemony of mouse-as-laboratory-animal model. There is now a vast literature that supports the reproducibility of experiments with mice - experiments that do not require great expenditures on expensive cancer reagents thanks to the mouse's small size and the fact that it is one of the few possible lab animals that can be handled with the image production technologies used in the LUB. However, as we shall see below, this still didn't mean that there weren't "mishaps" when employing rats and mice as test subjects, opening up for question just how stable they actually are in this role.

The fact is that the historical collaboration between scientists and mouse breeders/fanciers already situated mice as unique among other pets, particularly because people and institutions were already protesting against the scientific use of dogs and cats at the beginning of the zoth century. Unlike rodents, both of these animals were already clearly morally evaluated as positive by society in general (Thomas, 2010; Carvalho and Waizbort, 2012). One must also take into account that (unlike clinical studies involving

7 In his study among cetologists, Calheiros (2009) points to a genetic proximity between humans and cetaceans that is created by a commensal consubstantiation: both species can be affected by the ingestion of the same pollutants. Rats and humans are generally linked by phylogenetic consubstantiality, which makes it possible for mouse/rat bodies to stand in for human counterparts in lab experiments. 
dogs) the first experiments with mice were genetics studies that did not involve invasive interventions such as cuts and surgery. In most cases, the studies were developed through observation, reproduction and the crossing of breeding lineages, which made it easier for the relatively few mice fanciers to accept the research, particularly given the fact that before the 1920s, the main political discussion among anti-vivisectionists orbited around the pain and suffering animals experienced in lab experiments. But this state of affairs would not remain unchanged. In a few decades, Little and his partners would be generating tumors in mice and engaging in much more radical procedures than simple observation and selective breeding. Little in fact believed he could transform rodents into "pure reagents", creating almost genetic copies of mice through inbreeding (Rader, idem, 35-36).

In other words, mice were animals that were close enough to humans when it came to sharing substances and phylogenetic history, but sufficiently distant as to not generate higher ethical and moral questions ${ }^{8}$. And here we can see the ambivalent and productive role of analogy in science. As evidenced by Nancy Stepan (1994) in an article on nineteenth-century research that addressed race and gender, scientific metaphors do much more than just establish equivalencies between things. Metaphors that actually work generally have a reciprocal action, producing something that goes beyond the two isolated statements that interact in the metaphor. The public dissection of the bodies of dead criminals in the early days of experimental physiology and perception of rodents as parasites and dirty thieves may thus have played an important role in constituting the murine body as the perfect and legitimate analogy for the production of a replacement "scapegoat" and its sacrifice in favor of a supposed diminution of human suffering. As Haraway suggests, as "a tool-weapon for 'stalking cancer', the bioengineered mouse is simultaneously a metaphor, the technology, and the beast living its many-layered life the best it can" (1997: 83) ${ }^{9}$.

In contrast to primatology (where there is room for the individual naming of animals which highlight the genealogical links between generations of monkeys and generations of primatologists (Sá, 2006)), the rats and mice used in lab experiments are generally not individually named, by individuals. And where the old hand drawn cards of amateur fanciers took into account aesthetic and behavioral criteria, the mouse names employed by contemporary science are based almost exclusively on genetic variations among the various strains. In order to differentiate between different groups of animals, scientists make small perforations in their ears and markings with a special pen. This was the case of the rodents I observed in the LUB.

Many varieties of rats and mice that have emerged in the course of this historical process of stabilization and rodents have gradually ceased to be objects of study in and of themselves and began to be used increasingly as laboratory equipment for various research projects. Among the mouse strains commonly found in Biomedical Ultrasound Laboratory are some descended from a common Mus musculus ancestor, such as BALB / c, SWR and 129 / SVJ. The Balb / $\mathrm{c}$ is a pretty old lineage, which arose directly from the relationship between scientists and enthusiasts at the beginning of the last century. Characterized by its albino and red-eyed members, the strain has undergone several selections throughout the first half of the twentieth century. Popular in science, BALB / c now has hundreds of sublineages. It was chosen by the laboratory's researchers because of its tendency to develop gastrointestinal tumors. Descendants of the Swiss strain (which arrived in the US from Switzerland in the mid-1920s), SWR mice, by contrast, are considered to respond better to chemicals used in the laboratory in order to induce tumors and inflammations. Meanwhile, the 129 / SVJ lineage has a genotype prone to tumor formation because they are heterozygous for a recessive gene responsible for tumor suppression.

8 It's worth remembering here the western ambivalence that Ingold claims exists (1995) between humanity as a species and humanity as a condition. If, as a species we are closer to rodents than to cats or dogs, from a moral point of view much closer to "our" cats and dogs.

9 "Many times it's the idea of a new metaphor that guides the scientist" (Jacob, 1998). See Knorr-Cetina (1981: 49-67) about the unstable, interactional and transformative character of metaphors in laboratory practices. 
Following the fate of their ancestors then, these three mouse strains proved viable as "oncomodelos", either because of a "natural" propensity for developing tumors, or because of their sensitivity to certain cancer-inducing chemicals. With respect to rats, the species traditionally used as a test animal is Rattus norvegicus, commonly known as the brown rat. Its Wistar lineage was present at the LUB, and - given that this is albino like the Balb mouse - it was also known as the white lab rat. The albino Rattus norvegicus, like Mus musculus mice, were one of the first species widely used as the go-to animal for laboratory experiments (see Logan, 2001). About twenty-five centimeters long, with a tail nearly the length of the rest of its body, and weighing up to five hundred grams, rats are much larger than mice (which do not grow longer than ten centimeters or weigh more than thirty grams). In the wild, mice may even end up as meals for hungry rats. In vivariums, they are companions in neighboring cages, supposedly as "vulnerable" as their potential rat predators.

\section{Producing oncorodents}

As we have seen above, scientific experimentation with rodents has most recently focused on trying genetically and experimentally to control test animal lineages so that these animals can be useful analogies of the (un)healthy human body. However, the animals possess singular characteristics, no matter how much they have been genetically homogenized. This is in part because, importantly, they are not machines, but rather living creatures endowed with intentionality and interests. It is also due to the fact that they have diverse relationships with humans and other living beings during their lives - and this doesn't even mention the technoscientific changes to which they are subjected! In the second part of this article, we will accompany the quest to make rodents animals that are minimally legitimate and interesting as test subjects and, at the same time, look at these animals' resilience, recalcitrance, resistance and their ability to destabilize their role as test subjects within the scientific projects that have created them.

I would like to begin with a story that illustrates the geographic, scientific and genealogical shifts that rodents can incite in a laboratory. It has to do with a long-standing academic discussion between myself and a postdoctoral researcher colleague at the LUB, carried out in the corridors and cafeterias of the Lab. Ana told me the story of a researcher with whom she had roomed during her doctorate in molecular biology. Proud and happy that her colleague would soon be defending her thesis, Ana was nevertheless worried because the research in question had been quite delicate, involving experimental difficulties. In spite of this, Ana told me her colleague's story in a good-humored tone, as if it were inevitable, given the many similar and uncontrollable events that occur in the quotidian work of the laboratory.

According to Ana, her friend initially wanted to study stroke physiology utilizing a murine model. To do this, she had ordered an expensive Japanese strain of female rats. The lineage in question is well known for a genetically selected profile that display highs levels of stress and aggression, dying early from stroke and heart attack. Because they are very skittish, they generally don't copulate and rebuff any male rat who approaches them for sex. Upon arrival in Brazil, however, the Japanese rats showed very different behavior from that expected by the scientists. Unlike their relatives back home in Japan, the rats which arrived in our country were quite calm and tranquil. Even too tranquil, said the researchers. Without any apparent stress, they began to copulate frequently with the Brazilian males and eat less compulsively, living in considerable harmony with the other animals. Concerned, the researchers sought solutions which would push their newly acquired and expensive test animals to develop the necessary conditions in order to suffer a stroke. They switched out their feed for a richer, more fatty variety, hoping that this would help spark a pathological incident. But, again contrary to expectations, the rats just grew fat and continued living quietly in their cages. Even swapping the cages for smaller spaces didn't seem to disturb the animals' 
generally sanguine outlook. Amid much laughter, Ana and I anecdotally concluded: "The rats became tropicalized!"

Ana was worried about her colleague's future, given that her thesis research was being undermined by her uncooperative lab rats. One of the possible ways she thought that the problem might be resolved was through creating artificial strokes in the animals through precise blows to certain regions of their heads. Ana allowed that this might be possible, but that it wasn't a very desirable solution, given that artificiallyinduced strokes wouldn't provoke the same sorts of physiological alterations as natural strokes. This would compromise her colleague's data, particularly with regards to its use in studying naturally occurring strokes in humans. She thought that it might be better for her friend to change her research focus entirely and look into why these changes had occurred in the rats in the first place. Was it the environment? But what, specifically, in the environment could've caused this situation? The climate? The food? The vivarium? The proximity of other animals? Was it perhaps some difference in the way in which the animals were treated? But what difference(s)? Was it something done by the vivarium's technicians, the researchers, or both? ${ }^{10}$ Finally, the researcher apparently decided to abandon these questions entirely and ended up defending a research project that was based on in vitro methodologies.

Regardless of what finally happened, the story raises relevant questions for any kind of science conducted with living beings as objects of study. Contrary to what a hasty analysis might lead one to believe, I do not think that such an event reduces the credibility of the trajectory and effort of selective breeding of natural strains, promoted over the years by scientists, which we've superficially discussed above. I'm also sure that the fact that Ana told me this story in a humorous tone, narrating unpredictable events and the imponderable facts of research, means that she's skeptical about genetic engineering of research lineages. Destructive irony was not the main point of her narrative.

Rather, Ana's story highlights quotidian dilemmas encountered in the use of living beings in lab experiments. Here, the "dissident" rats refused to annihilate themselves, as science had designed them to do. This, in turn, shifted the researcher's focus to other topics of study, creating the questions that Ana and I would chat about in our discussions. Our laughter (using the terminology adopted by Stengers (2002:85)) wasn't "at the expense of" the researcher and her rats: it was "shared with" her in the face of a more general perplexity. It expressed a common uncertainty.

In an interesting article entitled Os dispositivos experimentais (Experimental Apparatuses), Vinciane Despret (2011) relates some cases which can be productively thought of together with the story of the Japanese rats. The author describes research undertaken with rats in the 1960 s by Robert Rosenthal, a psychologist at a U.S. American university. Rosenthal presented two groups of animals to his students: one of them was made up of above- average animals from a lineage selected by a renowned researcher; the other was made up of mediocre animals. The students (also divided into two groups) were to subject both groups to labyrinth tests and thus verify the difference in performance between the two.

As Rosenthal expected, the students' results showed a large degree of difference between the performance of the two varieties of animals. Rosenthal then revealed to the students that both groups of rats were made up of common animals, bought at the local pet store. Rosenthal then triumphantly lectured his students about the power and influence of researchers' subjective expectations could have on the results of their studies. He had shown that the students whose rats performed better had developed more intense affective relations with their lab animals. In order to underline his warnings about the dangers of this influence, Rosenthal finally asked his secretary (who was not informed about the rats' supposed differences) to redo the tests. The result? Both groups of rats had the same average performance.

10 Souza (2013), for example, talks about the curious presence of photos showing mouse babies sleeping piled on top of each other that were pinned to the bulletin board of the vivarium where she undertook his fieldwork. According to Souza, these photos were probably posted by the vivarium's technicians. 
Rosenthal's experiment had as its ultimate objective the elimination of the evil influences of researchers' subjectivity from scientific procedures (and, incidentally, called into question the division between scientists and laymen by opposing his students' research to that of his secretary). Despret, however, would create another interesting interpretation of Rosenthal's results, looking positively upon the affect that was implied in the experiment and creating two alternative conclusions. First of all, Despret pointed out that the secretary also acted in accordance with Rosenthal's expectations: informed that the rats were more or less homogeneous and nothing special, she treated them as such and got average results across the board. By acting "as if" the rats were of one or another quality, both students and secretary ended up recreating given expectations about how these animals would act. In other words, relationship regimes, in this case, seem to have created existence regimes. Secondly, Despret pointed out that Rosenthal didn't take into consideration the students' expectations, which may have led them to be fooled out of a greater desire to please their professor by providing the results they assumed he wanted.

We have thus arrived at something close to that which Isabelle Stengers (2002: 177) understands as the working conditions of scientists who deal with living creatures that are capable of "interesting themselves" in the questions being formulated by the researcher, or who are capable of interpreting the experimental apparatus in their own manner. The object of study's interest might be formulated in this manner: "What does he want from me?" And this is not only applicable to scientific practices related to animal experimentation, but also to any knowledge produced through the study of beings that are endowed with intentionality and interests (anthropology, for example). As Despret points out, these sciences deal with "living creatures that never stop interpreting the propositions that are placed before them (2011: 51).

It may thus be interesting to consider some of the proposals of the author Elizabeth Costello, a character in J.M Coetzee's "A Vida dos Animais" ("The Lives of Animals", 2009). Costello raises the crucial - what we could perhaps call a Stengerian - possibility that a test animal might interest itself in a very distinct and different manner from the questions that scientists are using it to investigate. It may, in fact, formulate other questions that are possibly more relevant and central to it in the situation in which scientists place it. "What is particularly interesting about the story of the "tropicalized" Japanese rats, however, is that the "enigmatic" influence that the rats exercised did not take place in a more behavior-oriented experiment (in which one would presume that the animals might have more opportunities to express interest and affect): it happened in an experiment that was much more "instrumentalist" in nature. Here, the rats were not so much active in their interests, but simply not "performing" as expected as organic models in the course of research designed to develop new medical technologies for use with humans ${ }^{12}$.

Although the LUB has existed since the 1980s, it was only in 2006 that some of the lab's researchers began to utilize animals systematically in their experiments. Even so, work with lab animals is not generalized among the institution's scientists today. Only one of the professors (Pedro) undertakes in vivo experiments together with the students that he mentors. Another two professors have mentored and still mentor students who conduct research through vivisection, although these professors do not directly

11 In the same book, Costello tells the story of Sultan, a monkey who was the subject of several psychological experiments undertaken at the beginning of the $20^{\text {th }}$ century by the Prussian Academy of Sciences. According to Costello, "each time, Sultan was pushed to have a less interesting thought. From the purity of speculation - why does man behave like this? - he was ruthlessly pushed to a lower, more practical, and instrumental level - how can I use this to get that? - and was thus forced to accept himself, primordially, as an organism with an appetite to be satisfied. (...) In his deepest self, Sultan was not interested in the problem of the banana. It was the mind of the researcher, obsessively turned to the problem, that forced Sultan to concentrate on the banana. The question that really occupies the rat and the cat and any other laboratory or zoo animal is this: "Where is my home and how can I get there?" (Coetzee 2009: $36-37$ ).

12 There are controversies between biologists and other experimental scientists working with the murine model around the discussion of inborn and/ or learned behaviors concerning different generations and strains of animals. Apart from the opposition between mechanistic biology (which usually sees behavior as a "genetically programmed" phenomenon) and some Lamarckian theories (which consider that behavior can also generate an inherited inheritance), there are still those who advocate the hypothesis of causation "Formative causation," in which a kind of "morphic resonance" could act by shuffling the boundaries between the inborn and the acquired. For an interesting discussion of a serie of experiments with rats to revise such opposition between inheritance and behavior, see: http://www.sheldrake.org/about-rupert-sheldrake/blog/rat-learning-and-morphic-resonance. I thank Peter Fry for the reference to this discussion. 
participate in the process. As for the students, one can say that only a relatively small segment of them deals directly with living animals in the course of their research.

In 2005, Pedro returned from a post-doctorate in Canada, bringing with him a new line of research based on biomicroscopic ultrasound (BMU). This is a technology that uses high frequency ultrasonic radiation to produce medical images of intracorporal cavities and also of the body's surface. The name, "biomicroscopic ultrasound", came about as a result of the "microscopic" resolution of the images of live tissues obtained through this imaging technique. The fine resolution of these images is very close to that produced by optical microscopes. When BMU is applied to small animals such as rodents, the high frequency radiation is even more essential to maintaining the resolution's realism than it is when ultrasound is applied to humans.

Later, BMU, or micro-ultrasound, began to be instrumentalized in in vivo longitudinal studies while utilizing two varieties of rodent test subjects: mice, initially, then rats. Pedro thought that one way to foment dialogue and work in partnership with doctors and health researchers would be to undertake preclinical studies with living models in areas that would interest medical practitioners. It was then that Pedro was invited to become a professor in a graduate program in experimental surgery and began to invest in the new possibilities that were opening up in lab animal-based research. Pedro's trajectory is interesting in that it contrasts strongly with the beginnings of the use of animals as experimental subjects in the lab. Clarence Little, who was mentioned above as a U.S. American forerunner in animal experimentation, had to work hard to convince the medical profession of the value of the use of test animals. He associated rodent studies with public health problems such as cancer and thus succeeded in overcoming the skepticism of medical doctors who did not see the use of animal testing adding anything of relevance to their profession, unlike clinical tests with human beings (cf.Rader 2004). Pedro's trajectory took an opposite tack: he felt the need to conduct tests with lab animals precisely in order to gain more allies in the field of medicine. This was due to the fact that animal experimentation is well consolidated as a practice today and is seen as one of the principal markers of legitimacy for new health techniques and technologies. Pedro, who is an engineer, claims that the health researchers and professionals were not much interested in virtual models, test bodies and in vitro methodologies, given that these do not involve living organisms and thus could not be rapidly incorporated into clinical practices.

Although the members of the LUB use other materials and parts of animal bodies in their research, I would like to concentrate now on their use of living animals in laboratory tests. In the Lab, test animals are used to study lesions created in their muscle and bone tissue and to ultrasonically identify induced muscular hypertrophy. There are also used to help improve diagnostic images of certain pathological conditions. I will only analyze this second method of animal use here, due to space considerations and also because these were the sorts of experiments that I was most often able to personally follow myself.

Researchers do not have much time to handle the lab animals personally given that the studies are being conducted in an engineering institute that does not have a vivarium. This means that they do not have the capability to look after the beasts properly, feeding, cleaning and caring for them, as well as providing them with adequate light, temperature and air circulation. At most, the animals might stay overnight in the Lab if the experiments cannot be concluded in one day. This is not considered to be an ideal situation, given that the lab animal's food may attract the wild animals that are present on campus, including the lab mice and rats' "sewer cousins". Aside from putting the Lab's integrity and the safety of the scientists at risk, such an "invasion" might end up contaminating the test animals and, through them, the entire vivarium. Test animals are thus generally transported to the institute in their cages by car and are taken back to their vivariums on the same day. 
The test animals come from different institutes and live in different vivariums. They are selected according to the various relationships and alliances that the LUB's researchers establish with other research centers. One batch of mice from the $129 /$ Svj lineage (which have a genotype that facilitates the formation of tumors) was even imported from the United States via a donation by a professor linked to a cancer research center at the University of California. But experiments are also undertaken with mice bred from this lineage here in Brazil. Other mice are obtained through the university's vivariums and research labs or are bought from other universities which produce test animals in large scale for their own use and for sale to other institutes.

The researchers produce cancer in the intestinal tissues of the mice through a single injection of carcinogenic acid via a vein in the animal's tail. In the past, it was more common to observe the growth of spontaneous tumors, or to transplant tumors from other rodent lineages (cf. Rader, 2004). Transplants are still carried out today. It's more common, however, to induce lesions and tumors chemically and this is standard practice at the LUB. After administering the injection, the scientists wait a few weeks for the tumor to begin to develop. During this period, the animal may be subjected to occasional check-ups.

Originally, the carcinogenic injection was applied to the animal's abdominal region, but experiments showed that injection through the tail was preferable. When they began using mice, the Lab's researchers had difficulty finding the small tail vein and maintaining it intact while injecting it with the carcinogenic substance. This is a complicated task which might result in losing the animal through hemorrhage. More: each ampule costs around a thousand dollars and has a life expectancy of only two hours upon opening. When rats are used, the goal is not to produce tumors but simply an abdominal inflammation. A $3 \%$ solution of trinitrobenzenesulfonic acid is added to the rat's water for a week.

Once the tumors or inflammations are produced, the animal's weight is monitored and it is regularly checked for intestinal bleeding and feces consistency. As the injected/ingested substances irritate the animal's rectal and colonic mucus in a restricted fashion, they are seen to be a decent simulacrum for clinical conditions such as colitis and Crohn's Disease ${ }^{13}$. Both ailments can facilitate the development of colonic-rectal cancer.

According to the research undertaken at the LUB, BMU technology has the potential to decrease the need for biopsies, given that the images obtained through micro-ultrasound are increasingly as detailed as the results traditionally obtained through laborious histological work with dead tissue ${ }^{14}$. Other motives are also present in the justifications for the use of animal subjects in pre-clinical imaging, such as the limited number of people available for clinical studies and the greater ethical complications that arise with human testing.

Rodrigo, one of the LUB's researchers who, at the time, was working towards his masters in experimental surgery, likes to say that it's not a question of reproducing Crohn's Disease in rats. Rather, Rodrigo says, the Lab seeks to produce inflammations in rats that copy the effects of this disease to a certain degree. In other words, what we see in this case is an analogy to Crohn's Disease in humans that is made possible through the production of inflammations in rats. This analogy, of course, is based upon a prior analogy that compares murine bodies with human bodies. There was a certain need for rapidity in these experiments, given that the rodents tended to become better over time, which could impede the production

13 Pathologies that are understood to be chronic and which effect the human digestive system. Although ulcerative colitis is an inflammation that is understood to be somewhat more mild than Crohn's Disease, both ailments possess the characteristics of auto-immune pathologies. This makes more definitive and completely effective treatment quite difficult. A history of the study of Crohn's disease, complete with an account of the test animal models created through chemically induced intestinal inflammations can be found in Gonçalves et al (2008).

14 According to what one of the researchers told me, the fact that high frequency ultrasound images are giving results that are ever more favorably comparable with those achieved by traditional histology may also mean that fewer animals will be sacrificed. Being able to accompany the development of pathological disease over tie via ultrasound will mean that it will no longer be necessary to sacrifice different animals in order to obtain histological cuts for each step of the experiment. 
of images of the lesions and ulcers in their intestines, making comparison with human pathologies difficult or impossible.

After the animal has been anesthetized, a tiny probe is inserted in its anus, which has been previously lubricated with an anesthetic gel. The probe is connected to a catheter and it contains a miniaturized ultrasonic transducer in the form of an ultrafine metal wire. This operates at a frequency of $4 \mathrm{oMHz}$ and it can turn up to 360 degrees in order to produce endoluminescent images. In truth, this is a very specific variety of endoscope: a flexible pediatric bronchialfibroscope, imported from Japan. Here we can see creative and controlled "improvisation" in the resolution of technical-scientific problems, with an airmailed endoscope, originally designed for use in pediatric clinics, can be transformed into colonoscope for scientific use with laboratory animals - in this case, mice. This is a performative use that connects humans and lab animals through technological tools which can be transmuted from one use to another. In other words, the possibility of making analogies between murine and human bodies means that the singular characteristics of mouse bodies must be taken into consideration, producing interesting and controlled adaptations of technologies originally developed for humans.

Iara Souza (2013) recalls the arrival of an echo-cardiogram made specifically for mice in the laboratory where she worked. The advantage of this new equipment was that it had been developed with the particular characteristics of the mouse heart in mind, given that this is much smaller than that of rats or humans, beating much more rapidly as well. The new equipment thus enabled a better view of these rodents' hearts, improving it to the degree where they could be seen almost as well as human hearts. According to Souza (idem: 262), "by taking into consideration the differences of the mouse's body, it became possible, through the apparatus, to see it as if it were human".

In both these cases, then (echocardiography and BMU), we see an oscillation between humans and mice through procedures that are undertaken "as if" the body of the one could be seen as the body of the other, either through tools specifically designed for this purpose or through adaptations of human tools to murine bodies.

As intestines are full of air, gasses often offer up resistance to the propagation of ultrasound. The probe was initially inserted through the animal's lubricated anus, but it was discovered that the lubricating gel also generated a large quantity of air bubbles. The researchers thus opted to inject water into the mice's intestines via the probe and this turned out to be a more effective technique. It was, however, difficult to judge the proper amount of water needed to create a good image without also killing the mice and this complicated the first attempts to make the experimental model work. But water wasn't injected solely in order to improve the contact between the transducer and the intestinal walls, eliminating air in the organ: it also eliminated any feces which might also block easy viewing of the region. Before being subjected to experimentation, the lab animals were generally given an intestinal cleaning via the injection of a warm and oily liquid through the anus. Even so, feces would still occasionally show up during the imaging process, compromising the quality of the intestinal images. Hemorrhages - either created by the test animal's ailment or through mishaps in inserting the probe - also occasionally impeded the experiments.

Other elements beside blood and feces can unexpectedly show up during the course of intestinal imaging with BMU. One day, it was accidentally discovered, via colonoscope imaging during an experiment, that the test animals were infected with worms. The vivarium was advised and the test animals were immediately quarantined. Vivariums generally take many precautions so that their animals do not become ill. Sickness can change an animal's clinical characteristics, altering data and ruining experiments. As the rodents share cages and food and often come in contact with one another's' urine and feces and end up contaminating each other. 
In producing oncorodents, it quickly becomes evident that not all of the test subjects develop the kind of ailments that are desired. This is a variation in the experiment that is expected to occur to at least some degree. See, for example Souza's comments (2013) on this sort of problem in the research she investigated. In the case under study here, however, many of the rodents ended up not developing inflammations when they were administered toxic substances and this ended up threatening the research project's results. A short while after they discovered the worm infection among the lab animals, the researchers noted that the mice from the strain they were working with seemed to be particularly resistant to the carcinogenic acid that was being administered to them. One of the hypotheses that was raised to explain this was that, aside from individual resistances, the mice may have developed their resistance due to contamination with worms or bacteria. After researching the topic, it was discovered that articles had already been published by other research centers that had encountered similar problems and had come up with the same hypothesis: that some parasites create a certain "preventive/prophylactic" effect.

What is curious about this episode is that the animals' contamination and its possible association with a decrease in the rate of intestinal inflammations led to the researchers thinking about worm infections as a possible inhibitor of intestinal pathologies ${ }^{15}$. This only occurred due to the accidental contamination of the highly controlled and purified vivarium environment, as Marras (2009) and Souza (2013) have discussed, and due to the fact that these particular scientists just happened to be working with intestinal imagery. This incident also demonstrates the difficulties inherent in controlling lab animal lineages that end up hosting other beings even when they are genetically modified to resist contamination by pathogens (Birke, 2003:209). Other non-human animals are thus making their presence felt in the experiment and demonstrating (via the lab animals and endoscopic technology) a certain implacable recalcitrance: worms.

In a mysterious book entitled "Le parasite", Michel Serres (1982[1980]) dealt with the diverse meanings and implications of the idea of parasitism. Looking at the multiple relationships forged between parasite and host, Serres expands the concept of parasitism beyond its strictly biological frontiers (which associates parasitism exclusively with invertebrate beings). According to the author, the science of parasitology carries with it a history of anthropomorphizing both the host and its (not always welcome) guest. We can think beyond this, however, says Serres. In French, parasite means both a parasitical being and a rupture created by static in a message in a communication system. Parasite can thus be thought of as something that provokes interruptions, interference, or noise. This is something quite similar to what the nematodes did in the rodent bodies, making them resistant to inflammation, interfering with ultrasonic radiation and - consequently - disrupting the diagnostic images the researchers sought to produce. The protection given to the rodents' intestines came in exchange for intra-organic food and shelter. In other words, the parasitical self-protection implied maintaining the guest alive and resistant.

But Serres (idem) also thinks of the parasitical dynamic via the image of a parasitical cascade. This cascade is understood as a sequential chain wherein all beings are parasites and hosts in some since ${ }^{16}$. As Gabriel Tarde reminds us: “... parasites also have parasites, and so on. Even though they might be infinitesimally small!” (Tarde, 2007:55). We can think of this circuit in the study at hand in the following

15 Helminth eggs have already been used to alleviate the symptoms of ulcerative colitis. These are ingested and they later proliferate in the large intestine. See: http://www.isaude.net/pt-BR/noticia/13085/ciencia-e-tecnologia/avaliada-eficacia-da-terapia-com-vermes-para-cura-da-colite-ulcerativa. Studies are also being undertaken regarding the efficacy of infection by the Schistosoma mansoni flatworms. These show that the worms increase rat resistance to asthma and allergies through the parasites' liberation of certain substances in the host organism. See: http://noticias.terra.com.br/ciencia/interna/o,,OI655158-EI298,oo. html. Also see: http://noticias.terra.com.br/ciencia/noticias/o,,OI769027-EI298,oo-Verme+pode+curar+doencas+inflamatorias+diz+estudo.html. Like worms, bacteria can also act as prophylactic agents in the intestine. As Haraway points out (2004,2008), certain types of bacteria have co-evolved with us, being responsible for making our intestines what they are today. This is why it is a current medical practice to transplant feces from a healthy individual into people with serious intestinal inflammations caused by harmful bacteria. New varieties of bacteria contained in the foreign feces help rebalance the intestinal flora and work more quickly and effectively than antibiotics.

16 "We parasite each other and live amidst parasites. Which is more or less a way of saying that they constitute our environment. We live in that black box called the collective; we live by it, on it and in it (...) There is no system without parasites" (Serres, 1982: 10-12). 
way: worms are parasites of wild rats who in turn are parasites of the lab, where they seek food and shelter. We are parasites of the rats and mice when we turn them into lab animals in our search for ways to end our suffering. Finally, our technical-scientific system exists parasitically on the knowledge we produce... and this isn't even mentioning the worms and bacteria that might be living as parasites in our bodies as we scrutinize and visualize the bodies of other beings. And it is here that we encounter the idea of companion species or co-evolution (Haraway 2004). In the words of Donna Haraway (2008) parodying Latour's aphorism: "We were never human". But, obviously, in this symbiopolitical movement (Helmreich 2009), not all parasites are equivalent and not all are worth what the cost.

\section{Final considerations}

In the LUB's more recent experiments involving ultrasound, microballs with antibiotics and luminescent agents ${ }^{17}$ have been inserted in the rodents' rectums. As the balls tend to shift towards the area where the tumor is growing, it will be possible to use high frequency ultrasound to map the vascular endothelial growth factor (VEGF). The VEGF indicates the vascularization region where the cancerous cells are growing, which permits a more precise prognostic regarding the progression of the disease. The Canadian scientist who pioneered the use of BMU talked about how bacteria is the probable future for high frequency ultrasound research. He made his comments during a special seminar on the occasion of his visit to the LUB. This researcher displayed photos of cyanobacteria, emphasizing their natural bioluminescence. He then asked why can't we think about modifying our own defensive cells so that these can produce their own bioluminescence and thus aid imaging technologies? New symbiopolitical possibilities are thus appearing on humanity's horizon, this time interrelating bioluminescent bacteria, humans, mice, and visualizing technologies.

We thus see micro-organisms' ambiguities in research. On the one hand, they can be seen as elements that disrupt scientific practices as funguses, bacteria, protozoans and etc. that attack artificial test bodies and animal parts that are not used in time or which have not been subjected to processes which slow down metabolic activities ${ }^{18}$. They are also seen as parasites that multiply within the bodies of test animals. Yet, on the other hand, they can be seen as experimental allies. The cyanobacteria mentioned above are one example of this, as are the funguses or substances produced by bacteria that are used in many experiments. There are also the beetle larvae that are used in certain stages of experiments, given that mice and rat bones must often be sent to laboratories in the biology institute and must thus be previously cleansed of all their flesh. In these cases, the bodies are tossed into larva vivariums and, after a few days, bones are retrieved, the flesh having been speedily and efficiently devoured by the larvas.

For these reasons and many more, it seems to me that we must take into consideration the inter- and transspecies relationships which we find among lab animals and their scientists. This implies that we must take a long look at how experimental science is actually undertaken and also how the lives of these various beings are constituted. The lab animal cannot be understood as a univocal and definitive phenomenon. At the same time, it's not possible for us to visualize a homogenous unity that totalizes all the experiments undertaken with animals in scientific laboratories.

\footnotetext{
17 The biomarkers are generally substances or drugs that permit us to accompany the occurrence of organic phenomena. In the case of the research undertaken at the LUB, they allow us to accompany the development of cancer cells.

18 The intestinal tube (removed from sacrificed animals) is full of micro-organisms and when it is exposed to the other microbeings present in the air, it quickly becomes an open-air "banquette" for the decomposing creatures that are found outside of our bodies. Armed with an electron microscope, we can accompany the galloping structural changes that take place in this tissue when it is exposed to the atmosphere. These changes ruin any attempt to study intestines "as they are" in the body when they are removed from it. Such dead fragments can never exist as they would when they bare part of a living body.
} 
It is thus more than necessary that we think about what lab animals provoke in science through these unpredicted happenings and their singularities as living beings. We also must think on the perplexities and questions that life in vivariums and the ways in which this is managed produce among scientists and their various research projects. Being ethnographically in tune with both axes of the test animal/science relationship - that which emphasizes the effects of scientific practices in the lives of lab animals and that which emphasizes the effects that the lives of lab animals produce in the science which scrutinizes their bodies - is thus a fundamental part of generating greater comprehension of the complex and multifaceted animal presence in science and of experiments with and of rodents.

Translated by Thaddeus Gregory Blanchette

Received: January, 3, 2016, Approved, June 16, 2016

\section{References}

AGAMBEN, Giorgio. 2012[2002]. O aberto. O homem e o animal. Lisboa: Edições 70 -Biblioteca de Filosofia Contemporânea.

BIRKE, Lynda. 2003. Who - or What - are the Rats (and Mice) in the Laboratory. Society and Animals, 11(3): 207-224

CALHEIROS, Orlando. 2009. As Transformações do Leviatã. Praxiografia de um Projeto de Cetologia. Masters dissertation - Programa de Pós-graduação em Antropologia Social/Museu Nacional/ Universidade Federal do Rio de Janeiro, Rio de Janeiro.

CARVALHO, Marcos C. 2015. Do ultrassom e seus corpos: tra(ns)duções e práticas de conhecimento em um laboratório universitário. Doctoral thesis. Programa de Pós-Graduação em Antropologia Social/Museu Nacional/UFRJ, Rio de Janeiro.

_. Complexidades da experimentação animal: sobre cientistas, cobaias e tecnologias biomédicas. In: BEVILAQUA, Ciméa e VELDEN, Felipe V (org.). Parentes, vítimas, sujeitos: perspectivas antropológicas sobre relação entre humanos e animais. Edufscar/Edufpr, 2016.

CARVALHO, André Luis de L. e WAIZBORT, Ricardo. 2012. Os mártires de Bernard: a sensibilidade do animal experimental como dilema ético do darwinismo na Inglaterra vitoriana. Scientiae Studia, 10(2):355-400. COETZEE, J.M. A vida dos animais. 2009 [1999]. São Paulo: Companhia das Letras.

DESPRET, Vinciane. 2011. Os dispositivos experimentais. Fractal: Revista de Psicologia, 23(1): 43-58.

FOUCAULT, Michel. 2000. As palavras e as coisas: uma arqueologia das ciências

GONÇALVES, Cely C. M., HERNANDES, Luzmarina, OLIVEIRA, Nelson L. B., NATALI, MARIA R. M.. 2008. Alternativas terapêuticas em modelos experimentais de doença inflamatória intestinal. Ciência, Cuidado e Saúde, n.7 (Suplemento): 107-111.

HARAWAY, Donna. 1997. Modest_witness@second_millenium. FemaleMan@meetsOncoMouse ${ }^{\mathrm{TM}}$ : feminism and technoscience. New York/London: Routledge.

. Manifesto ciborgue: ciência, tecnologia e feminismo-socialista no final do século XX. In: SILVA, Tomaz T. (org) Antropologia do ciborgue - as vertigens do pós-humano. Belo Horizonte: Autêntica, 2000

2004. The Companion Species Manifesto: Dogs, People and Significant Otherness. Chicago: Prickly Paradigm Press.

2008. When Species Meet. Minneapolis: University of Minnesota Prees.

2011. A partilha do sofrimento: relações instrumentais entre animais de laboratório e sua gente.

Horizontes Antropológicos, 17(35): 27-64. 
HELMREICH, Stephan. 2009. Alien Oceans: anthropological voyages in microbial seas. Berkeley: University of California Press.

HODART, Sophie. 2008. La cour des miracles. Ethnologie d'un laboratoire japonais. Paris: CNRS Editions. INGOLD, Tim. 1988. Preface to the paperback edition. In: (org.). What is an animal? Londres:

Routledge. . 1995. Humanidade e animalidade. Revista Brasileira de Ciências Sociais, 28: 39-53.

JACOB, François. 1998. O rato, a mosca e o homem. São Paulo: Companhia das Letras.

KNORR-CETINA, Karin. 1981. The manufactured of knowledge: an essay on the constructivist and contextual nature of science. Oxford: Pergamon Press.

. 1999. Epistemic cultures: how the sciences make knowledge. Cambridge/London: Harvard University Press.

KOHLER, Robert E. 1994. Lords of the Fly: drosophila genetics and the experimental life. Chicago: University of Chicago Press.

LATOUR, Bruno. 1996[1991]. Jamais fomos modernos: ensaio de antropologia simétrica. Rio de Janeiro: Editora 34 . . 200o[1985]. Ciência em Ação - Como Seguir Cientistas e Engenheiros Sociedade Afora. São Paulo: UNESP.

LOGAN, Cheryl A.. 2001. "[A]re norway rats... things?": diversity versus generality in the use of albino rats in experiments on development and sexuality. Journal of the History of Biology, 34(2): 287-314.

MARRAS, Stelio. 2009. Recintos e evolução: capítulos de antropologia da ciência e da modernidade. Doctoral thesis - Programa de Pós-Graduação em Antropologia da USP.

PAIXÃO, Rita L. e SCHRAMM, Fermin Roland. 2008. Experimentação animal: razões e emoções para uma ética. Niterói: EdUFF.

RADER, Karen. 2004. Making mice: standardizing animals for american biomedical research, 1900-1955. Princeton: Princeton UP.

SÁ, Guilherme José da S.. 2006. No mesmo galho: ciência, natureza e cultura nas relações entre primatólogos e primatas. Doctoral thesis - Programa de Pós-graduação em Antropologia Social/Museu Nacional/Universidade Federal do Rio de Janeiro, Rio de Janeiro.

SERRES, Michel. 1982. The parasite. Baltmore and London: The Johns Hopkins University Press.

SHELLEY, Mary. 1994[1818]. Frankenstein. New York: Dover Publications

SOUZA, Iara Maria de Almeida. 2013. "Vidas experimentais: humanos e roedores no laboratório".

Etnográfica, 17(2): 241-268.

STENGERS, Isabelle. 2002. A Invenção das Ciências Modernas. São Paulo: Editora 34.

STEPAN, Nancy Leys. 1994. "Raça e gênero: o papel da analogia na ciência" In: HOLLANDA, H. B. (Org.).

Tendências e Impasses: o feminismo como crítica da cultura. Rio de Janeiro: Rocco, p.72-96.

TARDE, Gabriel. 2007. Eduardo Vargas(org.). Monadologia e sociologia e outros ensaios de Gabriel Tarde. São Paulo: Cosac Naify.

THOMAS, Keith. 2010. O homem e o mundo natural: mudanças de atitude em relação às plantas e aos animais (1500-1800). São Paulo: Companhia das Letras.

UEXKÜLL, Jacob von. 1983. Dos animais e dos homens: digressões pelos seus próprios mundos. Lisboa:

Livros do Brasil.

\section{Marcos Castro Carvalho}

Doutor em Antropologia Social, Museu Nacional, Universidade Federal do Rio de Janeiro, Rio de Janeiro/RJ, Brazil.

E-mail: dabata@gmail.com 